\title{
Intravenous 1 gram tranexamic acid for prevention of blood loss and blood transfusion during caesarean section: a randomized case control study
}

\author{
Babita Ramani*, Lalmohan Nayak
}

Department of Obstetrics \& Gynecology, VSS Medical College \& Hospital Burla, Sambalpur, Odisha, India

\author{
Received: 26 March 2014 \\ Accepted: 14 April 2014 \\ *Correspondence: \\ Dr. Babita Ramani, \\ E-mail: babitaramani@gmail.com
}

(C) 2014 Ramani B et al. This is an open-access article distributed under the terms of the Creative Commons Attribution Non-Commercial License, which permits unrestricted non-commercial use, distribution, and reproduction in any medium, provided the original work is properly cited.

\begin{abstract}
Background: Aim of current study was to determine the effect of tranexamic acid in reducing blood loss during and after C-section.

Methods: All women undergoing LSCS were divided in two groups viz study and control group. All were requested for pre-op and post-op $\mathrm{Hb} \%, \mathrm{PCV}$ and TRBC. Intravenous tranexamic acid one gm was given to study group (not to control group) $10 \mathrm{~min}$ prior to skin incision and blood loss in both groups was calculated by weighing prewieghed pads soaked in blood.

Results: Post-op blood loss was significantly lower in study group $(\mathrm{P}=0.020)$. $\mathrm{Hb} \%$ changes in post-op period is significant in control group $(\mathrm{P}=0.037)$.
\end{abstract}

Conclusions: Tranexamic acid is safe and effective in preventing post-partum hemorrhage after caesarean section.

Keywords: Tranexamic acid, Post-partum hemorrhage, Caesarean section

\section{INTRODUCTION}

Rate of Post-Partum Hemorrhage (PPH) is more after Csection $(4 \%$ vs. $0.6 \%)$ than vaginal delivery ${ }^{1}$ and among these, $6 \%$ require blood transfusion ${ }^{2,3}$ and $11 \%$ suffers from severe post-partum anemia. ${ }^{4}$ Recently, Cesarean Section (CS) rates have increased to as high as $25-30 \%$ in many countries of the world like China and India, ${ }^{5}$ which would cause more PPH rates than normal vaginal delivery. Maternal mortality ratio is 200 in India ${ }^{6}$ and PPH still is a leading cause. ${ }^{4}$ Therefore, selection of effective prevention and treatment of PPH after CS should be a topic for researchers.

Tranexamic acid is biochemically Trans-4-(aminomethyl) cyclohexanecarboxylic acid $\left(\mathrm{C}_{8} \mathrm{H}_{15} \mathrm{NO}_{2}\right)$. Tranexamic acid was first reported by Okamoto in 1962. It is a synthetic derivative of lysine and antifibrinolytic agent. It is a reversible competitive blocker of lysin binding site on plasminogen and plasmin molecule which is responsible for fibrin degradation and at much higher concentrations, a noncompetitive inhibitor of plasmin. Tranexamic acid in a concentration of $1 \mathrm{mg}$ per $\mathrm{mL}$ does not aggregate platelets in vitro.

In obstetrics, tranexamic acid is used after delivery to reduce bleeding, often with syntocinon (oxytocin) and fundal massage. During delivery, when the placenta separates from the uterine wall, a sequence of physiologic and haemostatic changes occur that reduce bleeding: strong myometrial contractions, increased platelet activity and a massive release of coagulant factors but there is also a parallel increase in the fibrinolytic activity. ${ }^{8}$ The fibrinolytic system is activated after rapid reduction of fibrin and fibrinogen following the removal of the placenta, and fibrin destruction products are increased because plasminogen activators catalyze the conversion of plasminogen to plasmin. This activation can take up to 
$6-10 \mathrm{~h}$ in the postpartum period. Tranexamic acid can be effective in reducing obstetric bleeding, as it is a plasminogen activator inhibitor. As a result, there is a theoretical rationale for the use of antifibrinolytic agents in the treatment of postpartum haemorrhage. ${ }^{9-11}$

A major trial is in progress in different parts of world to establish the efficacy of the drug to arrest Post-Partum Hemorrhage (PPH). The CRASH-2 trial has evaluated that tranexamic acid significantly reduces mortality in trauma patients who are profusely bleeding. ${ }^{12,13}$ Based on these studies, tranexamic acid has been included in the WHO list of essential medicines. ${ }^{14}$ Tranexamic acid is not a new drug and it has been used for many years for treatment of menorrhagia and in teeth extraction in hemophiliac patients. ${ }^{15}$ Since last one decade, the role of tranexamic acid is being studied during caesarean section for prevention of PPH. This study is based on these hypotheses and will clarify the doubts of obstetricians about the use of this drug even in emergency caesarean section.

\section{Aims and objectives}

- To determine the effect of tranexamic acid in reducing blood loss during and after $\mathrm{C}$-section

- To highlight the use of tranexamic acid in decreasing the incidence of post-partum hemorrhage after Csection

- To assess the ability of tranexamic acid in reducing blood transfusion after C-section

- To determine the safety of tranexamic acid for both mother and fetus during and after $\mathrm{C}$-section

\section{METHODS}

\section{Study design}

Randomized control trial. O\&G department, VSS medical college \& Hospital, Burla from $1^{\text {st }}$ march 2013 to $30^{\text {th }}$ April 2013. Permission was taken from ethical committee of the college. Informed written consent was taken from all the women. Not supported by any pharma company. Tranexamic acid ampoules are supplied by govt. of Odisha, India.

All the patient undergoing C-section during the study period in emergency room were included except women having liver disorder, renal problem, heart diseases, HIV infected, h/o thrombosis, allergy to tranexamic acid, multifetal gestation, eclampsia and severe pre-eclampsia. All women were divided in two groups - study group and control group. All patient's pre-op and post op hemoglobin (Hb\%), hematocrit (PCV) and Total Red Blood Cell Count (TRBC) were done.

Study group received inj. tranexamic acid one gram intravenously, slowly $10 \mathrm{~min}$ prior to skin incision. Another dose of $500 \mathrm{mg}$ was given to those where bleeding continued at the end of caesarean section.
Control group were not given the same. All patients received $10 \mathrm{IU}$ of oxytocin infusion and $10 \mathrm{IU}$ as intramuscular along with $400 \mathrm{mcg}$ of tablet misoprostol sublingually and uterine massage after delivery of placenta.

\section{Calculation of blood loss}

Blood pressure, pulse, respiratory rate and blood loss during and within two hour of C-section were noted. After giving skin incision blood was soaked into preweighed 10x10 inches towels and entering the amniotic cavity, amniotic fluid was sucked up by vacuum. After removal of placenta bleeding was again taken into account. Two hours post-partum blood loss was calculated by weighing pre-weighed pads used by the women. Weighing pre-weighed towels soaked into blood and putting them into the following formula= Wet weight-dry weight/1.05 (1.05 is a constant). Postoperatively $\mathrm{Hb} \%$, hematocrit (PCV) \& Total RBC of all women were checked. All the women along with their babies were followed up for 7 days as it is the usual hospital stay for all post caesarean patients. Degree of freedom and student t-test were calculated and put into $\mathrm{P}$ value calculator of GraphPad Software to calculate $\mathrm{P}$ value.

\section{RESULTS}

Total 120 women participated and all LSCS done under spinal anesthesia. There were no statistically significant difference in subject's characteristic and vitals in both groups (Table 1). They were similar in respect to obstetric complication. There was no statistical difference in pre-operative systolic blood pressure, $\mathrm{Hb} \%, \mathrm{PCV}$ and TRBC of both the groups (Table 2). Mean time taken for LSCS is $41 \pm 10 \mathrm{~min}$ for study group and $43 \pm 10 \mathrm{~min}$ in control group. The intra-operative blood loss was not statistically significant $(\mathrm{P}=0.1372)$ but two hour postoperative blood loss was significant between both the groups $(\mathrm{P}=0.0204)$. Hence there was statistically significant difference in total blood loss between both the groups (0.0494) (Table 3). There were $19 \%$ and $27 \%$ reduction of blood loss in study group when compared to control group in pre-operative and post-operative period respectively.

Table 1: Comparison of subjects' characteristics in both groups.

\begin{tabular}{|llll|}
\hline Parameters & $\begin{array}{l}\text { Study } \\
\text { Mean } \pm \text { SD }\end{array}$ & $\begin{array}{l}\text { Control } \\
\text { Mean } \pm \text { SD }\end{array}$ & P value \\
\hline Age & $24.9 \pm 3.9$ & $24.4 \pm 3.7$ & 0.477 \\
\hline BMI & $24.9 \pm 3.3$ & $24.04 \pm 3.0$ & 0.141 \\
\hline Gravidity & $1.53 \pm 0.7$ & $1.56 \pm 0.6$ & 0.796 \\
\hline SBP & $125.4 \pm 9.9$ & $122.1 \pm 11.7$ & 0.096 \\
\hline DBP & $83.8 \pm 10.3$ & $79.1 \pm 10.2$ & 0.142 \\
\hline Interval & $40.6 \pm 9.8$ & $42.7 \pm 10.5$ & 0.292 \\
\hline
\end{tabular}


Table 2: Comparison of preoperative parameters in both groups.

\begin{tabular}{|llll|}
\hline Parameters & $\begin{array}{l}\text { Study gr. } \\
\text { Mean } \pm \text { SD }\end{array}$ & $\begin{array}{l}\text { Control gr. } \\
\text { Mean } \pm \text { SD }\end{array}$ & P value \\
\hline $\mathrm{Hb} \%$ & $10.5 \pm 1.15$ & $10.1 \pm 2.14$ & 0.069 \\
\hline $\mathrm{HTC} \%$ & $33.9 \pm 3.83$ & $32.6 \pm 4.47$ & 0.090 \\
\hline $\mathrm{TRBC} / \mathrm{cmm}$ & $3.9 \pm 0.59$ & $3.7 \pm 0.57$ & 0.079 \\
\hline
\end{tabular}

Table 3: Blood loss difference in both groups.

\begin{tabular}{|llll|}
\hline Blood loss $(\mathrm{ml})$ & $\begin{array}{l}\text { Study gr. } \\
\text { Mean } \pm \text { SD }\end{array}$ & $\begin{array}{l}\text { Control gr. } \\
\text { Mean } \pm \text { SD }\end{array}$ & $\begin{array}{l}\text { P } \\
\text { value }\end{array}$ \\
\hline INTR-OP & $190.7 \pm 100.41$ & $230 \pm 176.1$ & 0.317 \\
\hline POST-OP & $31.2 \pm 31.6$ & $44.07 \pm 27.8$ & 0.020 \\
\hline Total blood loss & $222.07 \pm 97.02$ & $274.5 \pm 179.2$ & 0.049 \\
\hline
\end{tabular}

Table 4: Difference of pre and post-operative Hb, PCV \&TRBCS of both groups.

\begin{tabular}{|lllllll|}
\hline \multirow{2}{*}{ Parameters } & \multicolumn{2}{l}{ Study gr. (Mean \pm SD) } & & Control gr. (Mean \pm SD) & \\
& Pre-op & Post-op & P value & Pre-op & Post-op & P value \\
\hline Hb\% & $10.5 \pm 1.15$ & $10.2 \pm 1.47$ & 0.215 & $10.1 \pm 1.24$ & $9.57 \pm 1.5$ & 0.037 \\
\hline PCV\% & $33.9 \pm 3.85$ & $32.5 \pm 4.05$ & 0.053 & $32.1 \pm 4.47$ & $31.62 \pm 4.53$ & 0.213 \\
\hline TRBC/cmm & $3.9 \pm 0.59$ & $3.8 \pm 0.54$ & 0.335 & $3.7 \pm 0.57$ & $3.6 \pm 0.56$ & 0.175 \\
\hline
\end{tabular}

Statistically significant difference was found in pre-op and post op $\mathrm{Hb} \%$ of control group $(\mathrm{P}=0.0371)$ than in study group $(\mathrm{P}=0.2157)$ (Table 4$)$. The difference between the mean $\mathrm{Hb} \%$ of both the groups were $0.3 \pm$ 0.32 and $0.63 \pm 0.25$ preoperative and post-operative respectively with statistically significant $\mathrm{P}$ value $(\mathrm{P}=$ 0.0001). Six women required blood transfusion in control group vs. only 2 women in study group $(\mathrm{P}=0.0462)$. Three of all women in study group were having sickle cell trait. No adverse effect was seen in mother and baby within 7 days.

\section{DISCUSSION}

Prevalence of anemia during pregnancy is very high. We are doing active management of third stage but still we are lacking somewhere and unable to judge the amount of blood loss during delivery in anemic and hypertensive patients, thus we are increasing the maternal mortality rate. Many of our pregnant women are suffering from sickling and sickle cell anemia.

We can treat anemia antenatally but when such patients come directly to emergency ward and indicated for emergency $\mathrm{C}$-section, we have no option left without blood transfusion because more blood loss will occur after an emergency $\mathrm{C}$-section. By injecting tranexamic acid prior to skin incision to the patients preparing for $\mathrm{C}$ section, we can prevent $19 \%$ intraoperative and $27 \%$ post-operative blood which have been proved by the present study and also prevent post-partum hemorrhage as well as blood transfusion rate.

Similar study was carried out by Gohel et al. 2007, ${ }^{16}$ where $1 \mathrm{gm}$ tranexamic acid reduces postoperative blood loss significantly $(\mathrm{P}=0.001)$. They used injection methergine in third stage active management. We used tab misoprostol $400 \mathrm{mcg}$ per rectal for active management of third stage as many of our patients were either hypertensive or become hypertensive intra operatively or post-operatively and that's why injection methergine is not used routinely in our institution. Jiunjun et al. 2012, ${ }^{17}$ given $10 \mathrm{mg} / \mathrm{kg}$ tranexamic acid as IV infusion $20 \mathrm{~min}$. before skin incision and found the same result, and both of these studies had used inj. methergine $2 \mathrm{mg}$ along with $10 \mathrm{IU}$ oxytocin, but we used sublingual misoprostol 400mcg sublingually instead of methergine. A multi-center, randomized trial was conducted by Gai et al. ${ }^{18}$ suggesting that approximately $18 \%$ reduction of blood loss was found in the experimental group. Besides, tranexamic acid has the ability to reduce the incidence of PPH in the study group, which is similar to the study by Gai et al. ${ }^{18}$ and Peitsidis et al. $^{7}$

We have more anemic population ( $\mathrm{Hb} \%$ as low as $2 \mathrm{gm}$ ). Here, all patients were under category of emergency caesarean section. Comparing these studies we can say that tranexamic acid is also effective in emergency cases where we require more hemostasis by $\mathrm{c}$ cauterizing or tying the bleeding points so that we can save total operative time. One more conflicting factor is the time of injection of tranexamic acid, it is $10 \mathrm{~min}$ and $20 \mathrm{~min}$ prior to skin incision in all the studies but we can improve the result by giving bolus dose of tranexamic acid intravenously even earlier as the half-life of tranexamic acid is 2 hours.

It is estimated that out of every 1000 women, $0.3-0.5$ of them are at risk of acquiring symptomatic venous thrombosis during pregnancy. ${ }^{12,19}$ This condition is only considered in theory and it was not observed in this study or either one of the above-mentioned studies. However, the risk of thromboembolism is five-time more during the postpartum period than antenatal period, even then no thromboembolic events appeared in the broad based, pragmatic, randomized double blinded controlled study 
called the Woman Trial (World Maternal Antifibrinolytic Trial) (2010). ${ }^{20}$

\section{CONCLUSION}

Tranexamic acid is significantly reducing the post caesarean blood loss even after emergency LSCS. Blood loss during caesarean section is also reduced. We can give answers to many surgeons that one gram tranexamic acid is beneficial for anemic women undergoing caesarean section and can prevent post-operative blood transfusion as well as the adverse effect of the same.

Funding: No funding sources

Conflict of interest: None declared

Ethical approval: The study was approved by the institutional ethics committee

\section{REFERENCES}

1. Wang BS, Zhou LF, Coulter D, Liang H, Zhong Y, Guo YN, et al. Effects of caesarean section on maternal health in low risk nulliparous women: a prospective matched cohort study in Shanghai, China. BMC Pregnancy Childbirth. 2010;10:78.

2. Gungorduk K, Yildim G. Efficacy of intravenous tranexamic acid in reducing blood loss after elective c-section: a prospective randomized, double blind placebo controlled study. Am J Perinatol. 2011;28(3):233-240.

3. Magonn EF, Evans S, Hutchinson M, Collins R, Lanneau G, Morrison JC. Post-partum hemorrhage after caesarean delivery: an analysis of risk factors. South Med J. 2005;98(7):681-5.

4. Abouzahr C. Global burden of maternal death and disability. Br Med Bull. 2003;67:1-11.

5. Kambo I et al. A critical appraisal of cesarean section rates at teaching hospitals in India. Int $\mathrm{J}$ Gynecol Obstet. 2002;79(2):151-8.

6. GOI, Office of Registrar General, India. Maternal \& child mortality and total fertility rates. Sample Registration System (SRS), 2011. Available at: http://censusindia.gov.in/vital_statistics/SRS_Bulleti ns/MMR_release_070711.pdf. Accessed 7 July 2011.

7. Peitsidis P, Kadir RA. Antifibrinolytic therapy with tranexamic acid in pregnancy and postpartum. Expert Opin Pharmacother. 2011;12(4):503-16.

8. Hellgren M. Hemostasis during normal pregnancy and puerperium. Semin Thromb Hemost. 2003;29(2):125-30.

9. Dunn CJ, Goa KL. Tranexamic acid: a review of its use in surgery and other indications. Drugs. 1999;57(6):1005-32.
10. Bonnar J et al. Clinical applications of fibrinolytic inhibition in gynecology. J Clin Pathol Suppl (R Coll Pathol). 1980;14:55-9.

11. Bolte AC, Bouma L, van Geijn HP. Medical therapies for primary postpartum hemorrhage. International Congress Series. Gynecol Obstet Reprod Med Daily Pract. 2005;1279:364-8.

12. Shakur $\mathrm{H}$ et al. Effects of tranexamic acid on death, vascular occlusive events, and blood transfusion in trauma patients with significant hemorrhage (CRASH-2): a randomised, placebo-controlled trial. Lancet. 2010;376(9734):23-32.

13. Roberts I et al. The importance of early treatment with tranexamic acid in bleeding trauma patients: an exploratory analysis of the CRASH-2 randomised controlled trial. Lancet. 2011;377(9771):1096101,1101-e12.

14. World Health Organization. Summary of the report of the 18th meeting of the WHO expert committee on the selection and use of essential medicines, 2011. Available at: http://www.who.int/selection_medicines/committees/ expert/18/en/index.html.

15. Cook L, Roberts I. Woman trial collaborators postpartum hemorrhage and the woman trial. Int $\mathbf{J}$ Epidemiol. 2010;39(4):949-50.

16. Gohel M, Patel P, Gupta A, Desai P. Efficacy of tranexamic acid in decreasing blood loss during and after cesarean section: a randomized case controlled prospective study. J Obstet Gynecol India. 2007 May/June;57(3):227-30.

17. Jianjun $X$, Wei G, Yingnan J. Tranexamic acid for the prevention of pos-tpartum hemorrhage after cesarean section: a double-blind randomization trial. Arch Gynecol Obstet. 2013 Mar;287(3):463-8.

18. Gai MY et al. Clinical observation of blood loss reduced by tranexamic acid during and after caesarian section: a multicenter, randomized trial. Euro J Obstet Gynecol Reprod Biol. 2004;112(2):154-7.

19. Toglia MR, Weg JG. Venous thromboembolism during pregnancy. N Eng J Med. 1996;335(2):10814.

20. Shakur H, Elbourne D, Gu“lmezoglu M, Alfirevic Z, Ronsmans C, Allen E, Roberts I. The woman trial (World maternal anti-fibrinolytic trial): tranexamic acid for the treatment of postpartum hemorrhage: an international randomised, double blind placebo controlled trial. Trials. 2010;16(11):40.

DOI: $10.5455 / 2320-1770 . i j r \operatorname{cog} 20140616$

Cite this article as: Ramani B, Nayak L.

Intravenous 1 gram tranexamic acid for prevention of blood loss and blood transfusion during caesarean section: a randomized case control study. Int J Reprod Contracept Obstet Gynecol 2014;3:366-9. 